ISSN 1392-3196 / e-ISSN 2335-8947

Zemdirbyste-Agriculture, vol. 108, No. 3 (2021), p. 255-262

DOI 10.13080/z-a.2021.108.033

\title{
Dynamics of soil organic matter in Panicum virgatum sole crops and intercrops
}

\author{
Anna TARANENKO, Maksym KULYK, Maryna GALYTSKA, Sergii TARANENKO, \\ Ilona ROZHKO
}

Poltava State Agrarian Academy, Department of Agrotechnology and Ecology

1/3 Skovorody, Poltava, 36003 Ukraine

E-mail: anna.taranenko@pdaa.edu.ua

\begin{abstract}
Soil organic matter (SOM) is one of the primary indicators of soil quality, which plays an important role in enhancing a range of soil physical, chemical and biological functions in the agricultural ecosystem. Switchgrass cultivation for bioenergy has the potential to improve and stabilize soil properties on marginal land over the years. The research was aimed to evaluate the dynamics of SOM in different types of switchgrass cropping systems and the influence of SOM on switchgrass productivity. The experiment was performed on a marginal land in the central part of the forest-steppe zone of Ukraine. The switchgrass (Panicum virgatum L.) cultivar 'Cave-in-Rock' was used. The experiment included two factors. Factor A - type of cropping: 1) sole crops of switchgrass (Sw) - control; 2) strip intercropping of switchgrass and lupine (Sw + strip); 3) mixed intercropping of switchgrass and lupine ( $\mathrm{Sw}+\mathrm{mix})$. Factor B - years of switchgrass cultivation (2010-2016). It was demonstrated that perennial switchgrass cultivation has the potential to increase SOM content. SOM content in $\mathrm{Sw}+$ strip crops increased by $0.12 \%$, in $\mathrm{Sw}+\mathrm{mix}-$ by $0.09 \%$ and in $\mathrm{Sw}-$ by $0.07 \%$. The highest switchgrass productivity was formed in $\mathrm{Sw}+$ strip (from 1.11 to $1.53 \mathrm{~kg} \mathrm{~m}^{-2}$ ) and in $\mathrm{Sw}+\operatorname{mix}$ (from 1.12 to $1.45 \mathrm{~kg} \mathrm{~m}^{-2}$ ) crops, the lowest - in Sw (from 0.85 to $1.34 \mathrm{~kg} \mathrm{~m}^{-2}$ ) crop. The maximum switchgrass productivity was observed for 5-7 years of cultivation. The highest height of plants and number of shoots of switchgrass were in Sw + strip crops, and significantly less in the other treatments. The results of the experiment showed a great increase of switchgrass productivity and SOM content in switchgrass crops and confirmed that switchgrass can be a sustainable energy crop.
\end{abstract}

Key words: soil organic matter, switchgrass productivity, types of switchgrass cropping.

\section{Introduction}

Soil is the largest organic carbon $\left(\mathrm{C}_{\mathrm{org}}\right)$ pool of the terrestrial ecosystems on earth, which interacts strongly with atmospheric composition, climate and land cover change (Jobbágy, Jackson, 2000). An integral part of any soil is organic matter. It is a complex of biomass and plant organic residues, animals, microorganisms and products of their metabolism. The main $\mathrm{C}$ inputs to the soil are: primary production (crop residues), root and weed biomass production. Aguilera et al. (2018) have reported average soil $\mathrm{C}$ inputs in the total cropland area from 2 to $2.4 \mathrm{Mg} \mathrm{C}^{-1} \mathrm{yr}^{-1}$.

Roots represented the majority of $\mathrm{C}$ inputs across most of the crop-management categories. Crop $\mathrm{C}$ allocated belowground represented a very significant fraction of soil $\mathrm{C}$ inputs. For example, in Spain, the average value of crop C inputs increased from $26 \%$ to $47 \%$ during the period from 1900 to 1980 . Total belowground contribution to soil $\mathrm{C}$ inputs including weeds ranged between $50-70 \%$ across all crop-management categories and periods. Weed biomass played a major role in the observed trends in soil $\mathrm{C}$ inputs. According to research data in Spain until 1960, it represented about 50\% and $75 \%$ of soil $\mathrm{C}$ inputs in herbaceous and woody crops.
Manure $\mathrm{C}$ inputs, which include the deposition of animals grazing in cropland, rose from 0.2 to $0.4 \mathrm{Mg} \mathrm{C} \mathrm{ha}^{-1} \mathrm{yr}^{-1}$ along the studied period, but their contribution to soil total $\mathrm{C}(\mathrm{C})$ inputs was always relatively low, ranging between $8-16 \%$. The role of urban waste in the $\mathrm{C}$ balance was always marginal, barely reaching $1 \%$ of soil $\mathrm{C}$ inputs in 2008 (Aguilera et al., 2018).

The soil organic carbon (SOC), acidity $(\mathrm{pH})$ and nutrient availability, electrical conductivity and infiltration are strongly interdependent in soils and primary indicators for evaluating soil quality in the agricultural ecosystem (Arshad, Martin, 2002).

Murphy (2015) showed that soil organic matter (SOM) is a key indicator of soil quality and plays an important role in enhancing a range of soil physical, chemical and biological functions. The storage of $\mathrm{C}_{\text {org }}$ in the soil depends on the balance between gains and losses of carbon. Biotic characteristics such as biomass production and microbial abundance, mean annual precipitation and temperature, soil characteristics including texture and lithology and anthropogenic activities, like land use and management, influence the processes of SOC storage or losses. A clear description of the distribution and changes

Please use the following format when citing the article:

Taranenko A., Kulyk M., Galytska M., Taranenko S., Rozhko I. 2021. Dynamics of soil organic matter in Panicum virgatum sole crops and intercrops. Zemdirbyste-Agriculture, 108 (3): 255-262. DOI 10.13080/z-a.2021.108.033 
of SOC and its factors of control will help predict the consequences of climate change (Albaladejo et al., 2013). In the soil ecosystem, SOM serves as a source of major plant nutrients such as nitrogen, phosphorus and sulphur (Sarker et al., 2018). The results of Aguilera et al. (2018) research show that SOM is key for soil fertility and for mitigation and adaptation to climate change, particularly in desertification-prone areas.

SOC dynamics are driven by changes in climate and land cover or land use. In natural ecosystems, the balance of SOC is determined by the gains through plant and other organic inputs and losses due to the turnover of organic matter (Smith et al., 2008). Increase of technological activities of people and global anthropogenic change affect SOC dynamics in multiple, often opposing, ways (Aguilera et al., 2018). Drying and wetting cycles are important factors controlling SOC dynamics (Jarvis et al., 2007), but they may have a limited effect on annual SOC changes (Borken, Matzner, 2009).

Carbon dynamics in cropland soils are a hot topic in the context of climate change. On the one hand, SOC is highly sensitive to management practices in these environments (Aguilera et al., 2013), and soil C sequestration can offset a large share of the full life cycle greenhouse gas (GHG) emissions of crop production (Guardia et al., 2016). SOC mineralization is affected by the changes in management practices such as tillage, irrigation and fertilization (Sainju et al., 2013).

The changes in management and climate exerted strong effects on SOM decomposition rates, which varied depending on the geographical distribution and specific agronomic features of each crop management category. In herbaceous crops with no management changes affecting decomposition rates humus decomposition rate increased by $21-34 \%$ with the lowest rates for winter cereal crops, cultivated mainly in a continental Mediterranean climate, and the highest rates for summer cereals, cultivated mainly in a temperate climate (Aguilera et al., 2018).

Tillage expansion was the main driver of SOM loss until the middle of the $20^{\text {th }}$ century, followed by the decline in soil $\mathrm{C}$ inputs during the extensive agriculture starting in the $1950 \mathrm{~s}$, which reduced harvest indices and weed biomass production. Return of crop residue started increasing in the 1980s. SOC content in 2008 was $17 \%$ (Aguilera et al., 2018). Also, results of this experiment showed that during the studied period crop yields increased by $227 \%$, but $\mathrm{C}_{\text {to }}$ exported from the agroecosystem increased only by $73 \%, \mathrm{~N}_{\text {tot }}$ - by $30 \%$ and soil C inputs - by $20 \%$; therefore, it can be said about decline in SOM during the $20^{\text {th }}$ century.

González-Sánchez et al. (2012) and Aguilera et al. (2013) showed that herbaceous perennial crops have been widely acknowledged as an effective soil C-building practice under Mediterranean conditions. Switchgrass production could restore SOC in surface soils. Farina et al. (2017) found higher SOC values for herbaceous crops in Southern Italy, which was associated with the high contribution of cover crops to soil C inputs.

In recent years, there has been increasing interest in the impact of agricultural management practices on SOC and nutrient cycling and storage worldwide (Hoyle et al., 2013; Kopittke et al., 2016). Lai et al. (2018) investigated the impact of switchgrass management on soil parameters, including SOC. The results of this experiment showed that the nitrogen fertilization rate did not significantly impact on soil parameters (including SOC) in switchgrass field.

Landscape position significantly influenced soil parameters in a switchgrass field. The SOC, total nitrogen $\left(\mathrm{N}_{\text {tot }}\right)$ and phosphorus $(\mathrm{P})$ contents and SOC stocks at the footslope position, generally, were significantly higher than those at the backslope and shoulder positions. Landscape position with slope can strongly influence both soil erosion and SOM distribution (Guzman, Al-Kaisi, 2011) and can be beneficial for improving soil properties (Lai et al., 2018). The SOC and $\mathrm{N}_{\text {tot }}$ content at the $0-5-\mathrm{cm}$ depth showed an increasing trend in switchgrass field. However, knowledge of how management practices influence the availability of nutrients for herbaceous perennial crops' growth, a key function of SOM, across diverse managed agro-ecosystems is limited (Hoyle et al., 2013).

Currently, in Ukraine, many negative factors affect the soil cover, which leads to such consequences as soil degradation and decreasing of SOM. According to the National Report on the State of Environment in Ukraine (https://mepr.gov.ua/news/31768.html), Ukraine has about 1 million hectares of marginal: degraded, unproductive and contaminated, land. Therefore, in Ukraine, land protection is one of the priorities of state policy in the field of environmental protection. And important task is the remediation of degraded lands restoring the sustainability of agricultural landscapes and reducing the anthropogenic load on the ecosystem. Phytoremediation aspects of energy crops use in Ukraine are described by Kulyk et al. (2019 b) and show that the removal of marginal lands from cultivation and formation of energy crops' phytocenosis on them have the potential to restore soil quality.

The research was aimed to evaluate the dynamics of soil organic matter (SOM) in different types of switchgrass crops and the influence of SOM on switchgrass productivity.

\section{Materials and methods}

An experiment was conducted in 2010-2016 in the central part of the forest-steppe zone of Ukraine $\left(49^{\circ} 00^{\prime} 36^{\prime \prime} \mathrm{N} ; 34^{\circ} 00^{\prime} 33^{\prime \prime} \mathrm{W}\right)$. The experiment was performed on a marginal land according to Dospekhov (1985). The size of the experimental plot was 50.0 $\mathrm{m}^{2}$. The switchgrass (Panicum virgatum L.) cultivar 'Cave-in-Rock' was used. The experiment included two factors. Factor A - type of cropping: 1) sole crops of switchgrass $(\mathrm{Sw})$ - control; row-spacing was $45 \mathrm{~cm}$ that forms conditions close to optimal for plant growth and development in the phytocenosis; 2) strip intercropping of switchgrass and lupine ( $\mathrm{Sw}+$ strip); crops on one plot of field with proper, beforehand specified alternation of rows or separate bands of crops; switchgrass is the main component and legume is a subsidiary one; seeds are not mixed and sown separately (by two agronomic operations); this method of plant cultivation is used for gaining maximum yield from the area unit with minimal production costs; 3) mixed intercropping of switchgrass and lupine $(\mathrm{Sw}+\mathrm{mix})$; perform twice-repeated, independent sowing of crops on the same area; this sowing method is mainly used for growing feed crops to obtain high yield of plant mixture. Factor B - years of switchgrass cultivation (2010-2016).

The information about soil basic properties is given in Table 1 . At the experimental site $(0-30 \mathrm{~cm}$ depth), the soil was Haplic Luvisol (WRB, 2014). In the soil of the experimental plots, the content of soil organic matter (SOM) and nitrogen (N) was low, phosphorus (P) content was high, potassium $(\mathrm{K})$ content was medium, and acidity $(\mathrm{pH})$ was close to neutral.

SOM content was determined by the method according to DSTU 4289:2004. The method implies organic carbon $\left(\mathrm{C}_{\mathrm{org}}\right)$ oxidation with 0.4 normality of the solution of potassium dichromate $\left(\mathrm{K}_{2} \mathrm{Cr}_{2} \mathrm{O}_{7}\right)$, prepared on concentrated sulphuric acid $\left(\mathrm{H}_{2} \mathrm{SO}_{4}\right)^{2}$ difuted in water in ratio $1: 1$. The amount of oxygen spent on oxidization of $\mathrm{C}_{\text {rr }}$ is determined by the difference between the amount of chromic mixture taken for oxidization and its non-used excess. Excess of oxygen not spent on humus oxidization is determined by oxidization of salt of iron oxide $(\mathrm{FeO})$ that is an ingredient of Mohr's salt $\left(\mathrm{FeSO}_{4}\left(\mathrm{NH}_{4}\right)_{2} \mathrm{SO}_{4} \times 6 \mathrm{H}_{2} \mathrm{O}\right)$.

The content of ammonium nitrogen $\left(\mathrm{NH}_{3}^{2}-\mathrm{N}\right)$ was determined by removing $\mathrm{NH}_{3}-\mathrm{N}$ from the soil with $1 \%$ potassium chloride $(\mathrm{KCl})$ solution in ratio $1: 10$. Shaking of soil suspension lasted for 1 hour (DSTU ISO/ TS 14256-1:2003). 
Table 1. Description of the topsoil (0-30 cm depth) properties of the experimental field

\begin{tabular}{ccc}
\hline Property & Parameter & Haplic Luvisol \\
\hline Soil type & & 3.17 \\
Soil organic matter & $\%$ & 81 \\
$\mathrm{NH}_{3}-\mathrm{N}$ & $\mathrm{mg} \mathrm{kg}^{-1}$ dry soil & 139 \\
$\mathrm{P}_{2} \mathrm{O}_{5}$ & $\mathrm{mg} \mathrm{kg}^{-1} \mathrm{dry}_{5}$ soil & 118 \\
$\mathrm{~K}_{2} \mathrm{O}$ & $\mathrm{mg} \mathrm{kg}^{-1}$ dry soil & 6.8 \\
Acidity $(\mathrm{pH})$ & & \\
\hline
\end{tabular}

The content of mobile $\mathrm{P}_{2} \mathrm{O}_{5}$ and $\mathrm{K}_{2} \mathrm{O}$ was determined by the method of Machigin according to DSTU 4114-2002. The method is based on removing mobile compounds of $\mathrm{P}$ and $\mathrm{K}$ from the soil with $1 \%$ ammonium carbonate solution $(\mathrm{pH}=9.0)$ with a soil and solution ratio $1: 20$ at $25 \pm 2{ }^{\circ} \mathrm{C}$ temperature. Shaking of soil suspension lasted for 5 minutes. Soil infusion in the solution lasted for 20 hours. Before determining mobile $\mathrm{P}_{2} \mathrm{O}_{5}$ and $\mathrm{K}_{2} \mathrm{O}$, soil extraction was discoloured with activated carbon. Phosphorus $(\mathrm{P})$ content was determined by a colorimetric method. To determine potassium $(\mathrm{K})$ content, a flame photometer C-115M1 (Ukraine) was used. Soil samples were prepared for analysis by drying $\left(\mathrm{t}=25 \pm 2{ }^{\circ} \mathrm{C}\right)$ and sifting.

The weather conditions of the switchgrass vegetation period (2010-2016) were favourable (Figures 1 and 2).

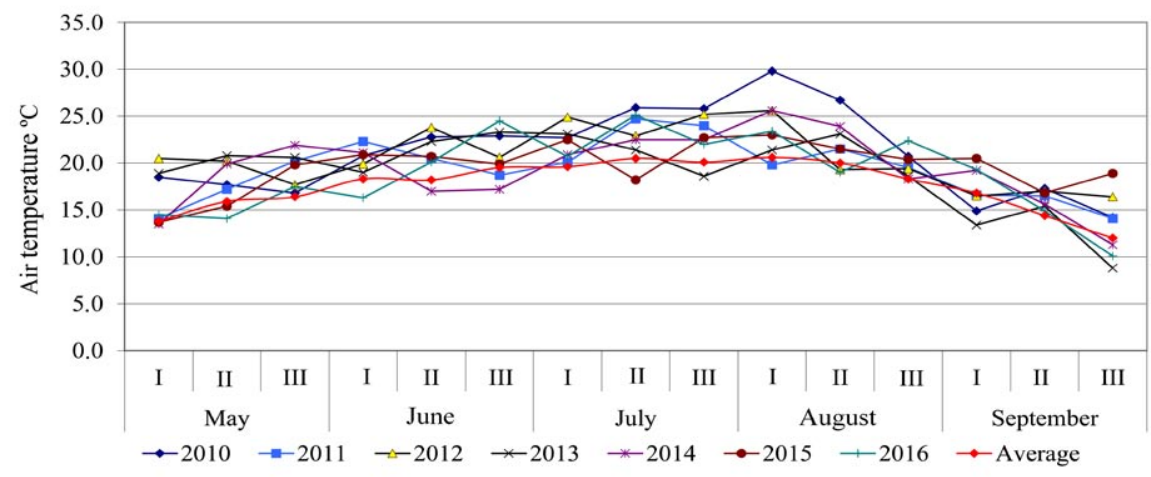

I, II, III - ten-day periods

Figure 1. Air temperature during the switchgrass cultivation years (2010-2016)

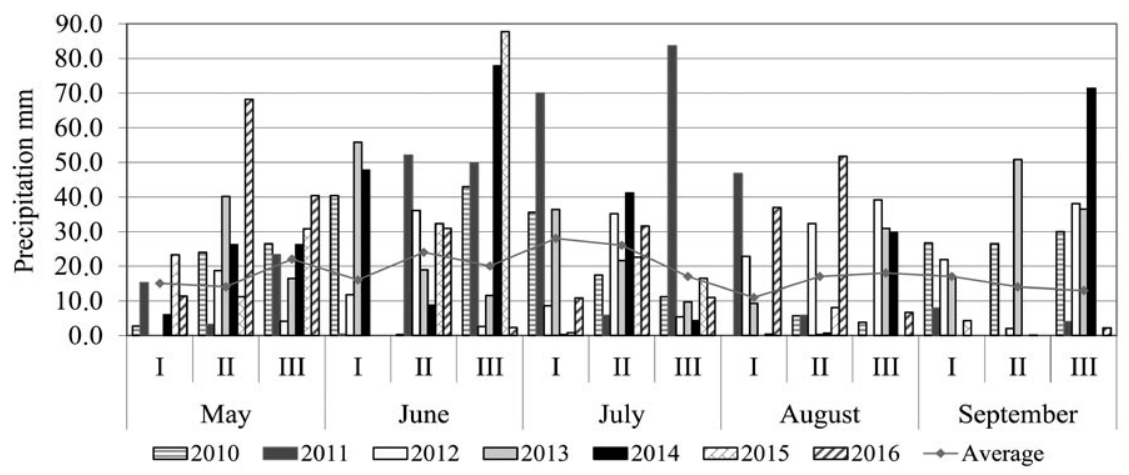

\section{I, II, III - ten-day periods}

Figure 2. Atmospheric precipitation during the switchgrass cultivation years (2010-2016)

During the experimental period, the average value of air temperature varied from $14.7^{\circ} \mathrm{C}$ to $23.7^{\circ} \mathrm{C}$ and was higher than the perennial average value; the amount of atmospheric precipitation was from 14.4 to $26.4 \mathrm{~mm}$. Hydrothermal coefficient (HTC) varied from 0.7 to 1.2 . According to HTC index, 2011-2013 years were dry, 2015 year was subhumid, 2010, 2014 and 2016 years were moderately humid.

Agricultural operations for switchgrass cultivation included ploughing ( $1^{\text {st }}$ ten-day period of September $)$, spring soil cultivation $\left(1^{\text {st }}\right.$ and $2^{\text {nd }}$ ten-day periods of April), seeding ( $3^{\text {rd }}$ ten-day period of April) and rolling the crop ( $3^{\text {rd }}$ ten-day period of October). In the first year of crop establishment, after the emergence of switchgrass shoots, multirow soil cultivation was carried out. In the following years, soil cultivation was not carried out, except for a spring application $\left(2^{\text {nd }}\right.$ ten-day period of April) of $30 \mathrm{~kg} \mathrm{ha}^{-1} \mathrm{NH}_{3}-\mathrm{N}$. Pesticides were not used in the experiment. Seeding of switchgrass was carried out in the $1^{\text {st }}$ ten-day period of May. The width between rows was $45 \mathrm{~cm}$ in all types of cropping. For seeding the switchgrass and lupine (Lupinus L.) the seed box of the drill was divided into sections by metal partitions to create rows of legume and the grass. The percentage of switchgrass seeds was $60 \%$, of lupine $-40 \%$. Switchgrass sowing rate was 300 seeds per $1 \mathrm{~m}^{2}$. The number of seeds was calculated based on germination, purity of seeds and recommended number per $1 \mathrm{~m}^{2}$.

The productivity of switchgrass aboveground mass was determined in the field by complete plot harvesting ( $3^{\text {rd }}$ ten-day period of October) at a height not less than $5 \mathrm{~cm}$. Cutting of the $1-\mathrm{m}^{2}$ wide plots was performed by special machines (mowing machine KSN1.4). Average dry matter aboveground mass was determined by weighing plants and then calculating on a per plant or per plot basis (Kulyk et al., 2017). Dry biomass yield was determined by drying $500 \mathrm{~g}$ of herbage samples at $105^{\circ} \mathrm{C}$ temperature to constant weight. The size of the experiment plot was $1 \mathrm{~m}^{2}$, four samples were taken diagonally from 
the plot. Lupine yield was not determined. Shoot height was recorded as the distance from the excised stem to the panicle. A hundred of shoots were measured to give an average value per plot. A count of shoot number in rows of $1 \mathrm{~m}$ was also made at harvest.

The experimental data were analysed with the software Statistica, version 6.0 (StatSoft Inc., USA). Analysis of variance (ANOVA) and correlational methods of statistical analysis were used for processing and interpretation of the results.

\section{Results and discussion}

Soil organic matter (SOM) content depending on the year of switchgrass cultivation. The average content of SOM at the beginning of the experiment was $3.17 \%$, at the end of experiment $-3.26 \%$. During the first two years of switchgrass cultivation, SOM content was $3.17-3.21 \%$, and increase of index was $0.02-0.04 \%$ in comparison with the control. In the following vegetation years, SOM content was 3.21-3.29\%, and increase of index was $0.07-0.12 \%$ in comparison with the control. Overall, SOM content increased by $0.09 \%$ during 7 years of switchgrass cultivation.

Statistical analysis confirmed the dependence: with each year of switchgrass cultivation SOM content increased (Figure 3).

Based on the results of the experiment, it can be concluded that multi-year switchgrass management had the potential to improve SOM content. Significant differences were proved by ANOVA.

Results of our experiment agree with those of Jobbágy and Jackson (2000), who showed that due to perennial life cycle, deep root system and considerable phytomass, energy crops improve the structures of soils and favour carbon uptake.

Molatudi et al. (2015) showed the effect of herbaceous crops on soil moisture, mineral $\mathrm{N}$ and $\mathrm{C}$ content of microbial biomass. It has been concluded that grassland planting has a beneficial effect on soil fertility in semi-arid regions by reducing $\mathrm{NO}_{3}-\mathrm{N}$ leaching and enhancing soil organic carbon. Other authors (Kantola et al., 2017) found that perennial grasses (switchgrass and miscanthus) do not require annual tillage and increase underground biomass, which is important for accumulation and conservation of SOM. SOM content increased from $31 \%$ to $71 \%$ over the 6 years of monocultures cultivation.

Studies in South Dakota (Liming et al., 2018)

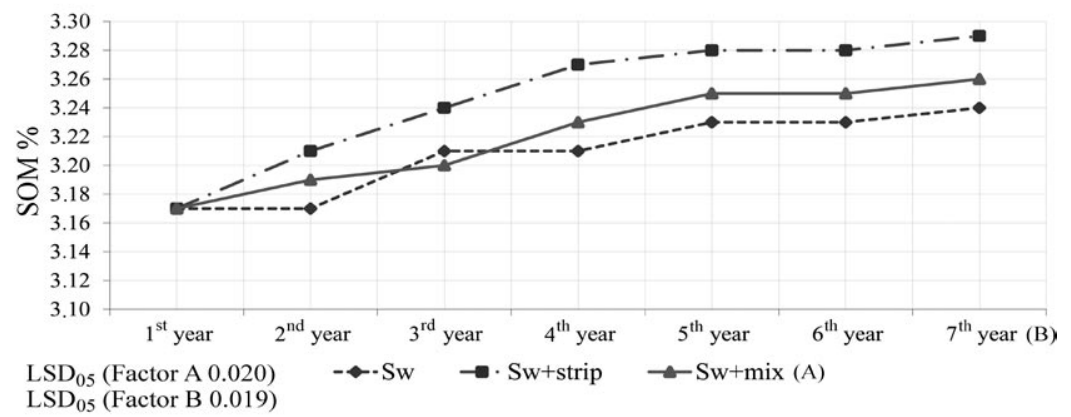

Factor B - year of switchgrass cultivation; Factor A - type of cropping: Sw - sole crops of switchgrass, Sw + strip - strip intercropping of switchgrass and lupine, $\mathrm{Sw}+\mathrm{mix}-$ mixed intercropping of switchgrass and lupine

Figure 3. Dynamics of soil organic matter (SOM) content depending on the type of switchgrass cropping and year of cultivation (2010-2016)

also confirmed that switchgrass is a sustainable energy crop, which improved and stabilized soil properties over many years of cultivation. SOM and $\mathrm{N}_{\text {tot }}$ content at the $0-5 \mathrm{~cm}$ depth had tendency to increase during the experimental years (2009-2013). However, the obtained data indicate that application of $\mathrm{N}$ had no effect on soil properties. Plant residues had an influence on improving soil properties. Therefore, energy crops can play an important role in SOM accumulation.

SOM content depending on the type of switchgrass cultivation. Results of the experiment showed increase of average value of SOM content under $\mathrm{Sw}+$ strip crop in the range from $3.17 \%$ to $3.29 \%$, substantially less increase of this index with $\mathrm{Sw}+$ mix - to $3.26 \%$ and the least increase with $\mathrm{Sw}$ - to $3.24 \%$.

Increase of average value of SOM in Sw + strip crop was caused by formation of more optimal sowing structure based on plant architectonics (morphological structure), favourable microclimate and development of root system for both crops. As a result, nutrient, water and light regime of soil improved under grain crops and legumes. Decrease of dynamics of SOM content in mixed intercropping was related to plant competition and heterogeneity. Vegetative mass of lupine after the end of plant vegetation remained in the field every year, which created an additional source of SOM. The relationship between the vegetative mass of lupine and SOM content is a prospect for our further research.

Statistical analysis showed the influence of type of switchgrass cultivation on SOM content during perennial cycle (Figure 4).

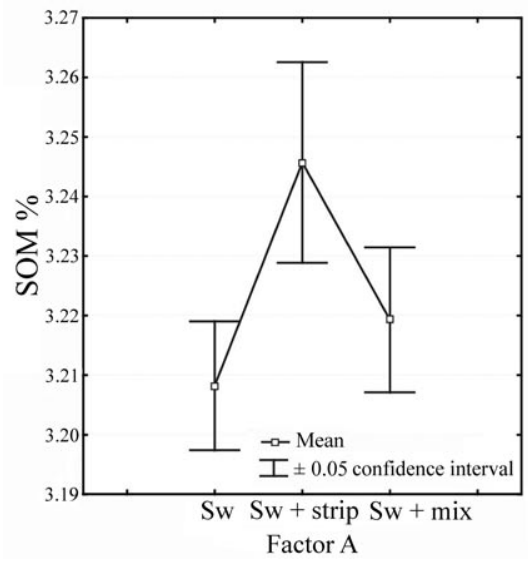

Factor A - type of cropping; Sw - sole crops of switchgrass, $\mathrm{Sw}+$ strip - strip intercropping of switchgrass and lupine, $\mathrm{Sw}+$ mix - mixed intercropping of switchgrass and lupine

Figure 4. The influence of type of switchgrass cultivation on soil organic matter (SOM) content

It was established that type of switchgrass cultivation had more influence on SOM index compared with year of cultivation. Spring N nutrition started since the $3^{\text {rd }}$ year of vegetation did not substantially affect dynamics of SOM content. Thus, the results of the experiment show that compared to the $1^{\text {st }}$ year of vegetation SOM content in the $7^{\text {th }}$ year of vegetation in 
$\mathrm{Sw}+$ strip crop increased by $0.12 \%$, in $\mathrm{Sw}+$ mix - by $0.09 \%$ and in Sw - by $0.07 \%$ (Figure 1). Such tendency allows to conclude that switchgrass management in $\mathrm{Sw}+$ strip crop with lupine is an effective way to increase soil fertility and stability.

Our research data confirmed the findings of Springer et al. (2001) that showed the effectiveness of switchgrass growing in combination with other crops. They studied complementary plant species as an alternative approach to pasture production. There were studied 6 monocultures and 15 binary mixtures, and the effectiveness of switchgrass with legumes was determined. A combination of these plants the biomass yield increased to $1360 \mathrm{~kg} \mathrm{ha}^{-1}$; the yield of IndiangrassIllinois bundleflower mixtures increased to $1230 \mathrm{~kg} \mathrm{ha}^{-1}$.

Perennial crops form a larger root biomass compared to annual crops, some of which can spread up to $3 \mathrm{~m}$ in depth, thereby, releasing more $\mathrm{C}$ and $\mathrm{N}$ into deeper soil layers than grain crops (Anderson-Teixeira et al., 2009). Research data in the south of the United States has shown that the use of perennial crops can increase SOM content and improve soil biological properties. Intercrops increase SOM content, soil microbial biomass and mineralization of SOM compared to conventional crop systems (Douf et al., 2013).

SOM content and switchgrass productivity (dry mass). Switchgrass productivity was measured from the third year of cultivation; during the experimental period, it ranged from 1.14 to $1.50 \mathrm{~kg} \mathrm{~m}^{-2}$ (Figure 5).

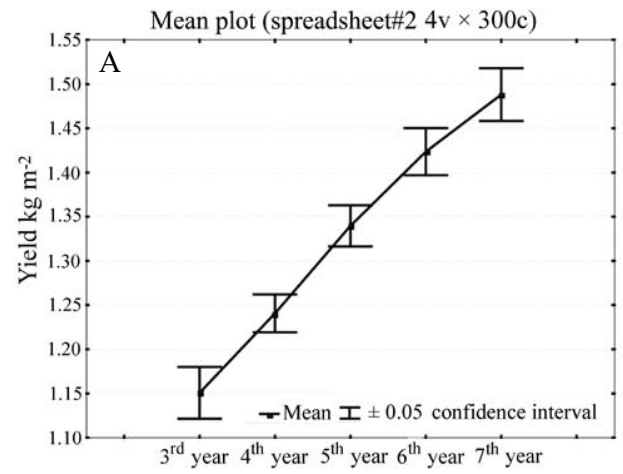

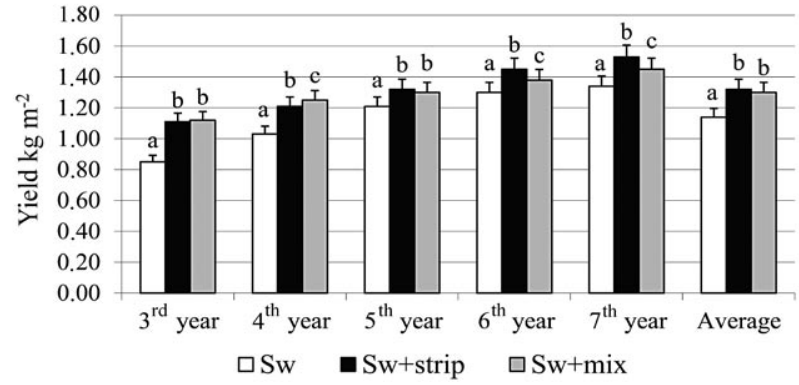

Note. $\mathrm{Sw}-$ sole crops of switchgrass, $\mathrm{Sw}+$ strip - strip intercropping of switchgrass and lupine, $\mathrm{Sw}+\operatorname{mix}-$ mixed intercropping of switchgrass and lupine; different letters show significant differences within each cultivar; $a, b, c-$ difference in variants significant according to ANOVA.

Figure 5. Average of switchgrass yield during the cultivation years (2013-2016)

The lowest value of switchgrass productivity was in Sw crop - from 0.85 to $1.34 \mathrm{~kg} \mathrm{~m}^{-2}$, in Sw + strip - from 1.11 to $1.53 \mathrm{~kg} \mathrm{~m}^{-2}$ and in $\mathrm{Sw}+\mathrm{mix}$ - from 1.12 to 1.45 $\mathrm{kg} \mathrm{m}^{-2}$. The highest index of switchgrass productivity was in $\mathrm{Sw}+$ mix crop - from 1.32 to $1.52 \mathrm{~kg} \mathrm{~m}^{-2}$ during 5-7 years of cultivation. The differences between treatments were proved by statistical dependences (Figure 6).

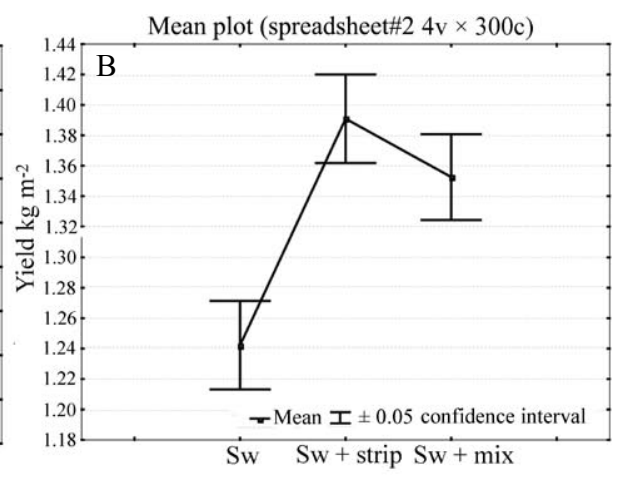

Note. $\mathrm{Sw}-$ sole crops of switchgrass, $\mathrm{Sw}+$ strip - strip intercropping of switchgrass and lupine, $\mathrm{Sw}+\mathrm{mix}-$ mixed intercropping of switchgrass and lupine; differences between the variance were $<0.05$.

Figure 6. The influence of years of switchgrass cultivation (2013-2016) (A) and types of cropping (B) on switchgrass yield

Difference of switchgrass productivity between $\mathrm{Sw}+$ strip and $\mathrm{Sw}+$ mix crops was $0.02 \mathrm{~kg} \mathrm{~m}^{-2}$, between $\mathrm{Sw}+\operatorname{mix}$ and $\mathrm{Sw}-0.16 \mathrm{~kg} \mathrm{~m}^{-2}$ and between $\mathrm{Sw}+$ strip and $\mathrm{Sw}-0.18 \mathrm{~kg} \mathrm{~m}^{-2}$. Therefore, switchgrass cultivation in $\mathrm{Sw}+$ strip with legume component showed high efficiency compared with Sw crops.

The results of our experiment show that switchgrass productivity increased over each year of the experiment. Generally, during the experimental period, average value of switchgrass productivity increased by $0.34 \mathrm{~kg} \mathrm{~m}^{-2}$; for one year of cultivation, switchgrass productivity increased by $0.0-0.2 \mathrm{~kg} \mathrm{~m}^{-2}$.

The results of our experiment showed considerable increase of switchgrass productivity and SOM content in switchgrass crops cultivated with a legume component. This fact was confirmed by the correlation analysis, which proved significant dependence between switchgrass productivity and SOM content: in $\mathrm{Sw}+\mathrm{mix}$, the correlation coefficient was $r=0.77$, in $\mathrm{Sw}$ + strip $-r=0.58$ (Figure 7).
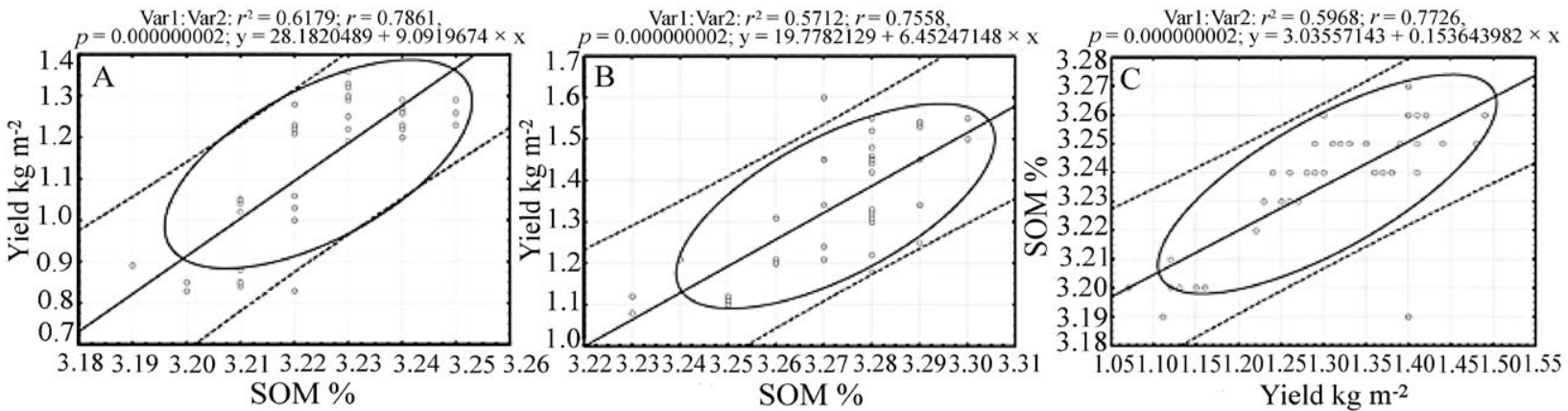

Figure 7. The relationship between switchgrass yield and soil organic matter (SOM) content in sole (Sw) (A), stripe $(\mathrm{Sw}+\mathrm{strip})(\mathrm{B})$ and mixed $(\mathrm{Sw}+\mathrm{mix})(\mathrm{C})$ crops 
Therefore, it can be concluded that switchgrass can be a sustainable energy crop. Switchgrass cultivation for bioenergy has the potential to improve and stabilize soil properties over the years. Xu et al. (2019) confirmed the results of our experiment that switchgrass productivity depends on SOM content. They suggest that in the long term, transgenic energy crops can produce more aboveground and underground biomass and increase the efficiency of biofuels production and sequestration of SOC. The authors suggest that aboveground and underground distribution of $\mathrm{C}$ inputs may be useful for restoration of marginal soil, especially at deeper soil layers. Therefore, switchgrass can be successfully cultivated on poor soils and water-restricted areas or marginal lands.

Quantitative indexes of switchgrass plants. The results of our experiment show considerable dynamics of quantitative indexes of switchgrass plants (Figure 8). Maximum indexes of height of switchgrass plants and number shoots were observed in $\mathrm{Sw}+$ strip crop with lupine. Significantly lower quantitative indexes of switchgrass plants were in $\mathrm{Sw}+\operatorname{mix}$ and $\mathrm{Sw}$ crops compared to $\mathrm{Sw}+$ strip.

The height of switchgrass plants was significantly lower in $\mathrm{Sw}+$ mix crop. This can be related to the fact that lupine plants occupy lower layer of crops and side rows of switchgrass plants were shady. The plants in the middle rows were higher than in the side rows. It is the
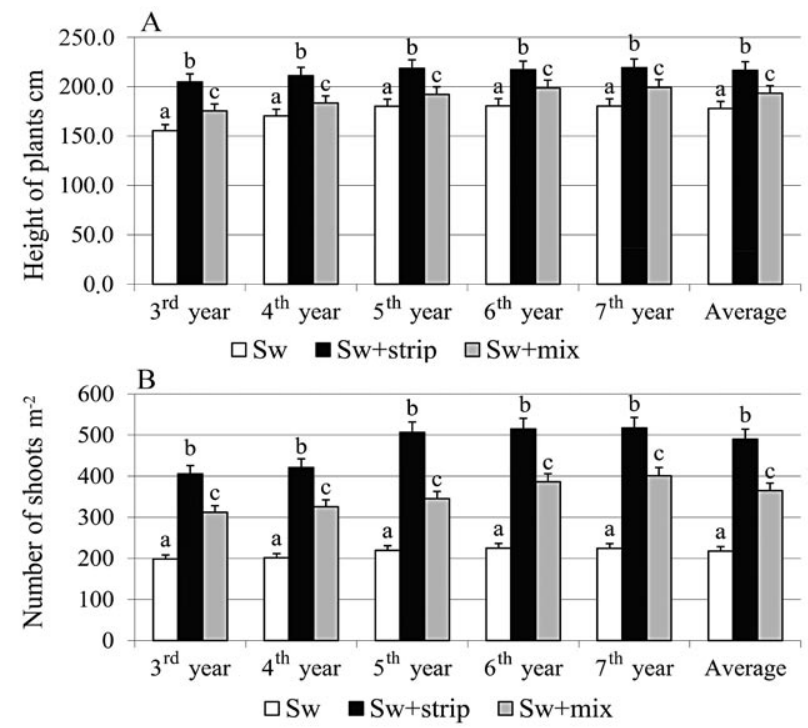

Note. $\mathrm{Sw}-$ sole crops, $\mathrm{Sw}+$ strip - stripe crops, $\mathrm{Sw}+$ mix - mixed crops; different letters show significant differences within each cultivar; $\mathrm{a}, \mathrm{b}, \mathrm{c}$ - difference in variants significant according to ANOVA.

Figure 8. The height of switchgrass plants (A) and number of shoots (B) during the cultivation years (2013-2016) influence of intraspecies competition for light. In this case the number of shoots in Sw crop was lower than in $\mathrm{Sw}+$ mix. This is the result of intensive growth of root system and side shoots of switchgrass plants. Switchgrass plants in $\mathrm{Sw}+$ strip were characterized by increasing height and number of shoots per meter compared with $\mathrm{Sw}$ and $\mathrm{Sw}+$ mix crops. The results of the experiment show increase in the trend of height of plants and number of shoots during switchgrass cultivation up to 5 years with subsequent stabilization during 6-7 years.

The statistical analysis showed the strong correlation $(r \geq 0.7)$, between biomass productivity and number of shoots per meter in all variants of crops (Figure 9).

Figure 10 shows the influence of plant height and number of shoots on switchgrass productivity in sole $(\mathrm{Sw})$ crops $(\mathrm{d}=0.77$ and 0.53$)$. For both indexes, correlation coefficient was $>0.7$.

Figure 11 shows different linear correlations between the number of shoots and switchgrass productivity in $\mathrm{Sw}+$ strip crop $(r=0.69)$. Plant height had medium influence on switchgrass productivity $(r=0.31$; $\mathrm{d}=0.10)$. Switchgrass productivity in $\mathrm{Sw}+$ mix crop depended on the number of shoots by $56 \%$ and height of plants by $29 \%(r=0.75$ and $r=0.54$, respectively $)$.

The results of our experiment confirmed that SOM content does not depend on the height of plants but is more dependent on the number of shoots. In Sw + strip and $\mathrm{Sw}+$ mix crops, the main factor which had influence on switchgrass productivity was the number of shoots $(r=$ 0.69 and $r=0.75$, respectively). In Sw crops, switchgrass productivity depended on the number of shoots $(r=0.76)$ and plant height $(r=0.88)$.

Kulyk et al. (2020) showed important influence of phytocoenosis components on soil and switchgrass productivity. Miesel et al. (2017) reported a decrease of switchgrass productivity during harvesting periods due to physical loss of leaves and inflorescence biomass. Although $\mathrm{N}$ application increased total aboveground biomass (biomass of leaves and inflorescences), it was concluded that $\mathrm{N}$ application increased shoot and leaf parameters. The main influence on the formation switchgrass biomass productivity was that of shoots. This agrees with the results of our previous research (Kulyk et al., 2019 a), which determined that from all components of the plant phytocenosis morphology structure the number of shoots had the greatest influence on the switchgrass productivity. This relationship was ascertained by McLaughlin and Walsh (1998) in the central and northern Great Plains, USA.

The results of our experiment are in line with those of Lemus et al. (2008) and Anderson et al. (2013), who indicated the domination of shoots in the total switchgrass phytomass. Over time, it can lead to improved biomass quality due to higher fibre content and lower $\mathrm{N}$ content in shoots. Improvement of biomass quality facilitates combustion technology and fermentation.
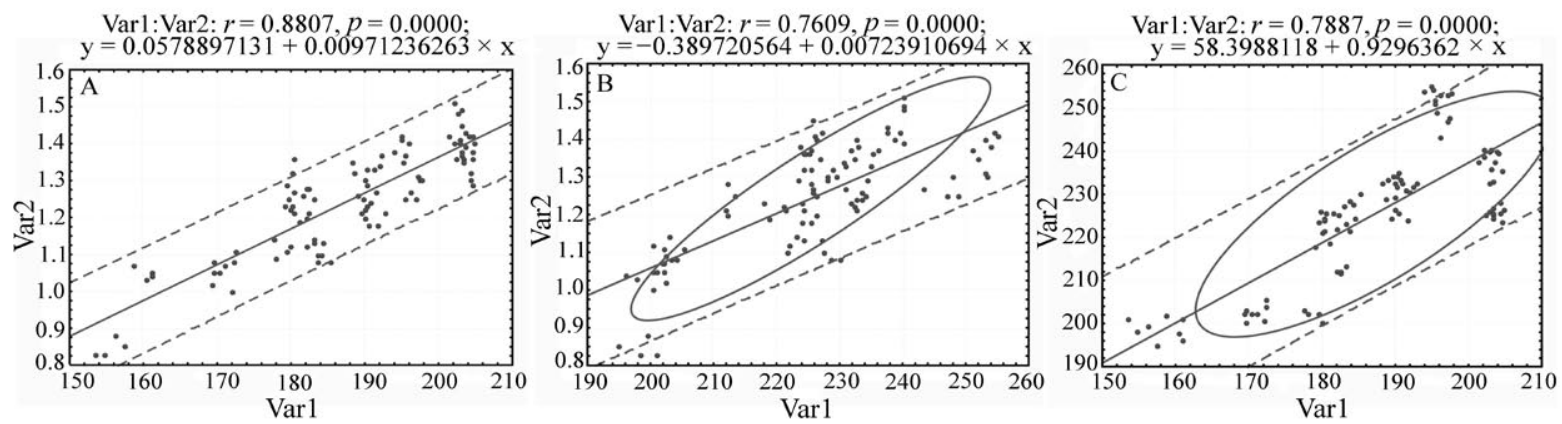

Var1 - height of plants, Var2 - switchgrass yield (A); Var1 - number of shoots, Var2 - switchgrass yield (B); Var1 - height of plants, Var2 - number of shoots (C)

Figure 9. The correlation between plant height, number of shoots and switchgrass yield in sole ( $\mathrm{Sw}$ ) crops 

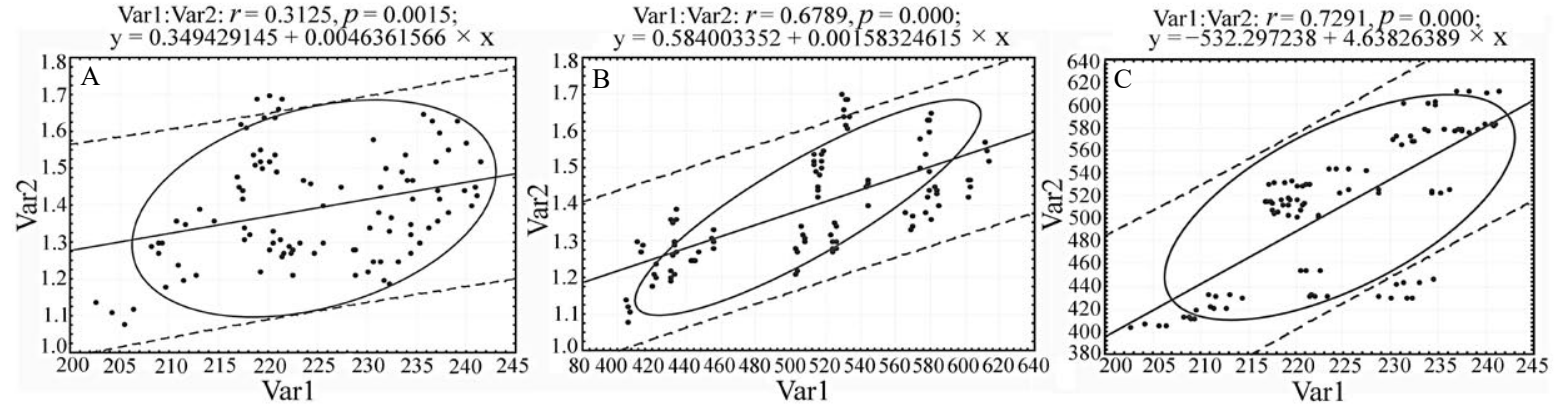

Var1 - height of plants, Var2 - switchgrass yield (A); Var1 - number of shoots, Var2 - switchgrass yield (B); Var1 - height of plants, Var2 - number of shoots (C)

Figure 10. The correlation between plant height and number of shoots and switchgrass yield in stripe (Sw + strip) crops
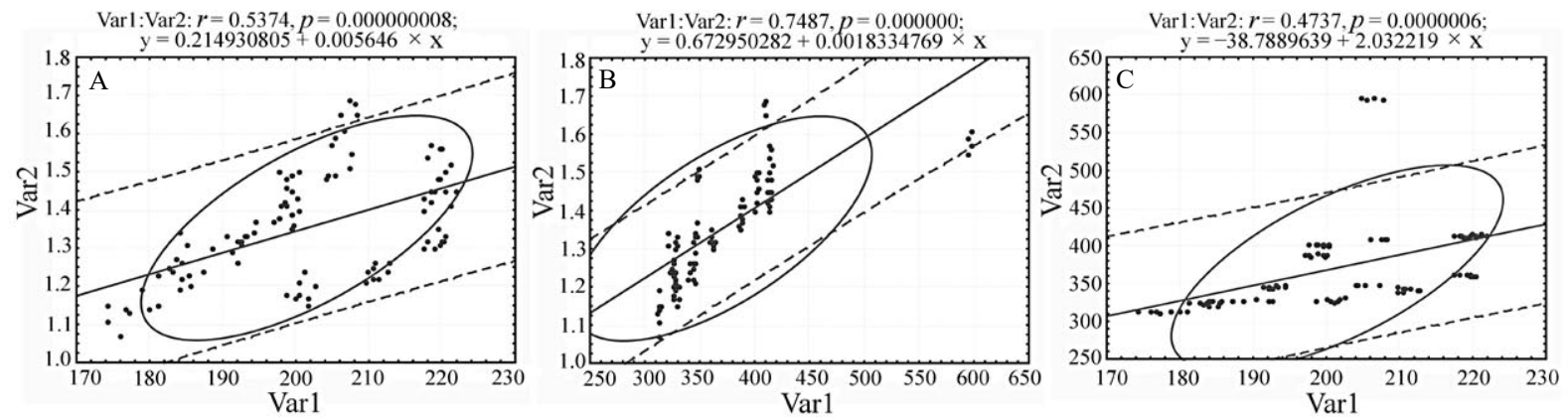

Var1 - height of plants, Var2 - switchgrass yield (A); Var1 - number of shoots, Var2 - switchgrass yield (B); Var1 - height of plants, Var2 - number of shoots $(\mathrm{C})$

Figure 11. The correlation between plant height, number of shoots and switchgrass yield in mixed ( $\mathrm{Sw}+\mathrm{mix}) \mathrm{crops}$

\section{Conclusions}

1. Soil organic matter (SOM) content depended on the year of switchgrass vegetation. SOM content increased with each year of switchgrass cultivation and confirmed that multi-year cultivation of this plant species has the potential to improve SOM content.

2. Dynamics of SOM content depended on the type of switchgrass cropping. Research results showed that switchgrass cultivation in strip intercropping ( $\mathrm{Sw}$ + strip) with lupine was effective. SOM content in strip intercropping of switchgrass and lupine $(\mathrm{Sw}+$ strip) increased by $0.12 \%$, in mixed intercropping of switchgrass and lupine (Sw + mix $)-$ by $0.09 \%$ and in sole crops of switchgrass $(\mathrm{Sw})$ - by $0.07 \%$.

3. Research results showed great increase of switchgrass productivity and SOM content in switchgrass crops. This confirms that switchgrass can be a sustainable energy crop and its cultivation for bioenergy has the potential to improve and stabilize soil properties over the years.

The results of this experiment may contribute to cultivation of energy crops on marginal land.

Received 18112020

Accepted 16062021

\section{References}

Aguilera E., Lassaletta L., Gattinger A., Gimeno B. S. 2013. Managing soil carbon for climate change mitigation and adaptation in Mediterranean cropping systems: a metaanalysis A criculture Frocvstems and Fnvironment, 168 25-36. https://doi.org/10.1016/j.agee.2013.02.003

Aguilera E., Guzmản G̈. İ., Áî̀varo-Fuentes J., İnfante-Amate J., García-Ruiz R., Carranza-Gallego G., Soto D., González de Molina M. 2018. A historical perspective on soil organic carbon in Mediterranean cropland (Spain, 1900-2008) Science of The Total Environment, 621:634-648. https://doi.org/10.1016/j.scitotenv.2017.11.243

Albaiadejo J., Urtiz K., Garcia-Franco N., Kuiz Navarro A. Almagro M., Pintado J. G., Martínez-Mena M. 2013. Land use and climate change impacts on soil organic carbon stocks in semi-arid Snain. Inurnal of Snils and Sediments, 13 (2): 265-277. https://doi.org/10.1007/s11368-012-0617-7
Anderson E. K., Parrish A. S., Voigt T. B., Owens V. N., Hon C.-H., Lee D. K. 2013. Nitrogen fertility and harvest management of switchgrass for sustainable bioenergy feedstock production in Illinois Industrial Crons and Prodints 48: 19-27. https://doi.org/10.1016/j.indcrop.2013.03.029

Anderson-leixeira K. J., Davis S. C., Masters M. D. DeLucia E. H. 2009. Changes in soil organic carbon under hinfuel crons FCR-Rineneroy 1 $175-96$ https://doi.org/10.1111/j.1757-1707.2008.01001.x

Arshad M. A., Martin S. 2UUL. Identifying critical limits for soil quality indicators in agro-ecosystems. Agriculture, Frosystems and Fnvirnnment 88 (?) $153-160$ https://doi.org/10.1016/S0167-8809'01)00252-3

Borken W., Matzner E. 2UUY. Keappraisal of drying and wetting effects on $\mathrm{C}$ and $\mathrm{N}$ mineralization and fluxes in soils Ginhal Change Rinlogy, $15(4) \cdot 808-824$. https://doi.org/10.1111/j.1365-2486,2008.0

Dospekhov В. А. Ічชว. Methodology of field experience [Методика полевого опыта]. Moscow, Russia, 336 p. (in Russian).

Douf F. G., Hons M., Ocumpaugh W. R., Read J. C., Hussey M. A. Muir J. P. 2013. Soil organic carbon pools under switchgrass grown as a bioenergy crop compared to other conventional crons Pedosnhere 23 (4): 409-416 https://doi.org/10.1016/S1002-0160(13)60033-8

Farina K., Marchetti A., Francaviglia K., Napoli K., Di Bene C. 2017. Modeling regional soil $\mathrm{C}$ stocks and $\mathrm{CO}$ emissions under Mediterranean cropping systems and soil types. A oriculture Frnsystems and Fnvirnnment, 238: 128-141. https://doi.org/10.1016/j.agee.2016.08.015

Gonzalez-Sanchez E. J., Urdonez-Fernandez R., CarbonellBojollo R., Veroz-González O., Gil-Ribes J A, 2012. Metaanalysis on atmospheric carbon capture in Spain through the use of conservation agriculture. Soil and Tillage Research, 122: 52-60. https://doi.org/10.1016/j.still.2012.03.001

Guardia G., Tellez-Kio A., Garcia-Marco S., MartinLammerding D., Tenorio J. L., Ibáñez M. Á., Vallejo A. 2016. Effect of tillage and crop (cereal versus legume) on greenhouse gas emissions and Global Warming Potential in a non-irrigated Mediterranean field. Agriculture, Erosystems and Envirnnment 221: 187-197. https://doi.org/10.1016/j. agee 2016.01.047

Guzman J. G., Ai-Kaisi M. M. 2UI I. Landscape position effect on selected soil physical properties of reconstructed prairies in southcentral Iowa Inurnal of Soil and Water Conservation, 69 (6): 574-580. https://doi.org/10.2489/jswc.66.3.183 
Hoyle F. C., D’Antuono M., Overheu T., Murphy D. V. 2013. Capacity for increasing soil organic carbon stocks in dryland agricultural systems. Soil Research, 51 (8): $657-$ 667. https://doi.org/10.1071/SR12373

Jarvis P., Key A., Petsikos C.., Wingate L., Kayment M., Pereira J., Banza J., David J., Miglietta F., Borghetti M., Manca G., Valentini R. 2007. Drying and wetting of Mediterranean soils stimulates decomposition and carbon dioxide emiscion: the "birch effect". Tree Physiology, 27 (7): 929 940. https://doi.org/10.1093/treephys/27.7.929

Jobbágy E. G., Jackson $\bar{K}$. B. Żं̄̄. The vertical distribution of soil organic carbon and its relation to climate and vegetation Ecological Annlications, 10 (2): 423-436. httns://doi org/10.1890/1051-0761(2000)010[0423:TVDOSO]Z.U.CUंZ

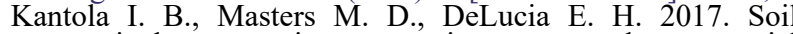
particulate organic matter increases under perennial bioenergy crop agriculture. Soil Biology and Biochemistry, 113: 184-191. https://www.life.illinois.edu/delucia/ $2014 \% 20$ Puhlications/Soil ParticulateOrganicMatter.pdf https://doi.org/10.1016/j.soilbio.2017.05.023

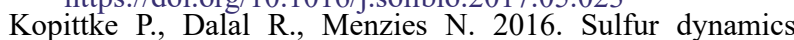
in sub-tropical soils of Australia as influenced by long-term cultivation. Plant and Soil, 402 (1-2): 211-219. http://search.ebscohost.com/login.aspx?dir est=true \& $d h=a n h \&_{r} \Delta N=114538406 \&_{r}$ site $=$ ehost-live https://doi.org/10.1007/s11104-015-2789-6

Kulyk M. 1., Kakhmetov D. B., Kurylo V. L. 201 7. Methodology of conducting field and laboratory researches with switchgrass (Panicum virgatum L.). Poltava, Ukraine, $24 \mathrm{p}$. http://dspace.pdaa.edu.ua:8080/handle/123456789/7586

Kulyk M., Shokalo N., Dinets O. 2019 (a). Morphometric indices of plants, biological peculiarities and productivity of industrial energy crops. Development of modern science: the experience of European countries and prospects for Itkraine: monogranh (3d ed ). Riga I atvia, p. 411-431. https://doi.org/10.30525/978-9934-571-78-7

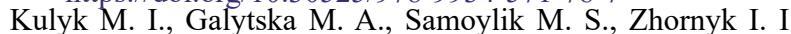
2019 (b). Phytoremediation aspects of energy crops use in Itkraine Agrology 2 (1): 65-73. https://doi.org/10.32819/2617-6106.2018.14020

Kulyk Mi.., Kurylo V., Pryshiliak N. N., Pryshiliak V. 2020 Efficiency of optimized technology of switchgrass biomass production for biofuel processing. Journal of Environmental Management and Touricm, 11 (1): 173-185. https://doi. org/10.14505//jemt.v11.1(41).20

Lai L̈., Kumar S.., Usborne S.., Ūwens V. N. 2018. Switchgrass impact on selected soil parameters, including soil organic carbon, within six years of estahlishment. CATENA, 163: 288-296. https://doi.org/10.1016/j.catena.2017.12.030

Lemus R., Brummer $\bar{C}$. $\bar{E}$., Lee $\bar{B}$., Mioore $\bar{K}$. J., Barker 'Ml. F., Molstad N. E. 2008. Effects of nitrogen fertilization on biomass yield and quality in large fields of established switchgrass in southern Iowa IISA Biomacs and Binenerovy 32 (12): 11871194. https://doi.org/10.1016/j.biombioe.2008.02.016

Liming L., Sandeep K., Shannon Ū., Vance N̄. Ū. 2018. Switchgrass impact on selected soil parameters, including soil organic carbon, within six years of establishment. CATENA 163: 288-296. https://doi.org/10.1016/j.catena.2017.12.030

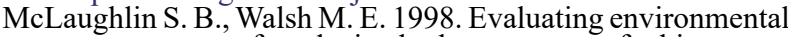
consequences of producing herbaceous crops for bioenergy. Biomass and Bioenergy, 14 (4): 317-324 https://doi.org/10.1016/S0961-9534(97)10066-6

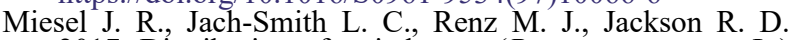
2017. Distribution of switchgrass (Panicum virgatum L.) aboveground biomass in response to nitrogen addition and across harvest dates. Rinmass and Rinenergy 100: 74-83. https://doi.org/10.1016/j.biombioe.2017.03.012

Molatudi $\bar{K}$. $\bar{L}$., Steinberger $\bar{Y}$., $\overline{\text { Nieng }} \overline{\mathrm{F}}$. $\bar{Y}$., Xie $\overline{\mathrm{U}}$. H. 2015. Effect of switchgrass plantation on soil moisture and nitrogen availability and microbial biomass carbon in a semi-arid ecosystem. International Journal of Agronomy and Agricultural Research (IJAAR), 7 (2): 130-141. https://www.researchgate.net/publication/323239406

Murphy B. W. 2015. Impact of soil organic matter on soil properties - a review with emphasis nn $\Delta$ unctralian soils. Soil Research, 53 (6): 605-635. https://doi.org/10.1071/SR14246

Sainju U. M., Stevens W. B., Evans K. G., Iversen W. M. 2U13. Irrigation system and tillage effects on soil carbon and nitrogen fractions. Soil Science Society of America Inurnal, 77: 1225-1234. https://doi.org/10.2136/sssaj2012.0412

Sarker J. R., Singh B. Y.., '̄ougherty W. J. J., Fang Y., Badigery W., Hoyle F. C., Dalal R. C., Cowie A. L. 2018. Impact of agricultural management practices on the nutrient supply potential of soil organic matter under long-term farming systems Soil and Tillage Research 175: $71-81$. https://doi.org/10.1016/j.still.2017.08.005

Smith P., Fang C., Dawson J. C.., İoncrieff J. B. 2008. Impact of global warming on soil organic carbon. Advances in A gronomy 97: 1-43. https://doi.org/10.1016/S0065-2113(07)00001-6

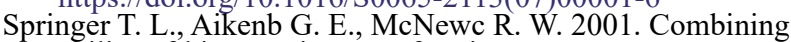
ability of binary mixtures of native, warm-season grasses and legumes. Cron Science, 41 (3): 818-823. https://doi.org/10.2135/cropsci2001.413818x

WRB. ZUं 14 . World reference base for soil resources. World Soil Resources Reports No. 106. FAO, 189 p.

Xu S., Ottinger S. L., Schaeffer S. M., Steward C. N. Jr. DeBruyn J. M., Stewart Jr. C. N., Mazarei M., Jagadamma S. 2019. Effects of field-grown transgenic switchgrass carbon innutts on soil organic carhon cvcling. PeerJ, 7: e7887. https://doi.org/10.7717/peerj. 7887

\title{
Dirvožemio organinès medžiagos dinamika Panicum virgatum vienanariuose pasẻliuose ir mišiniuose
}

\author{
A. Taranenko, M. Kulyk, M. Galytska, S. Taranenko, I. Rozhko \\ Poltavos valstybinès žemès ūkio akademija, Ukraina
}

\section{Santrauka}

Vienas pagrindinių dirvožemio kokybės rodiklių yra dirvožemio organinė medžiaga (DOM), turinti didelę reikšmę stiprinant ịvairias jo fizikines, chemines ir biologines funkcijas žemės ūkio ekosistemoje. Bioenergetikai skirtų daugiamečių rykštinių sorų auginimas turi potencialą pagerinti ir stabilizuoti nederlingų dirvožemių savybes. Tyrimo metu siekta įvertinti DOM dinamiką skirtingų tipų rykštinių sorų auginimo sistemose ir įtaką jų produktyvumui. Eksperimentas atliktas Ukrainos miškų ir stepių zonos centrinèje dalyje esančiame nederlingame dirvožemyje. Eksperimento metu augintos veislès 'Cave-in-Rock' rykštinès soros (Panicum virgatum L.). Eksperimentą sudare du veiksniai: A - pasėlių rūšys: 1) vienanaris rykštinès soros pasėlis (Sw, kontrolinis variantas); 2) juostiniu būdu pasètas rykštinių sorų ir lubinų mišinys ( $\mathrm{Sw}+$ juostinis); 3) rykštinių sorų ir lubinų mišinys (Sw + mišinys); B - rykštinių sorų auginimo metai (2010-2016 m.). Nustatyta, kad daugiamečių rykštinių sorų auginimas gali padidinti DOM kiekị: sorų ir lubinų mišinị pasejjus juostiniu būdu, jos kiekis padidèjo 0,12\%, soru ir lubinų mišinyje - 0,09 \%, vienanariame pasèlyje - 0,07\%. Didžiausias produktyvumas buvo sorų ir lubinų mišinị pasèjus juostiniu būdu (nuo 1,11 iki 1,53 $\mathrm{kg} \mathrm{m}^{-2}$ ) ir sorų bei lubinų mišinio (nuo 1,12 iki 1,45 $\mathrm{kg} \mathrm{m}^{-2}$ ), mažiausias - vienanario pasèlio (nuo 0,85 iki 1,34 $\mathrm{kg} \mathrm{m}^{-2}$ ). Didžiausias sorų produktyvumas nustatytas 5-7 auginimo metais. Didžiausias augalų aukštis ir ūglių skaičius buvo sorų ir lubinų mišinị pasėjus juostiniu būdu, kituose pasėliuose - esmingai mažesnis.

Eksperimento rezultatai parodė, kad rykštinių sorų produktyvumas ir DOM kiekis sorų pasèliuose labai padidejo, ir patvirtino, kad rykštinè sora gali būti tvarus energinis augalas.

Reikšminiai žodžiai: dirvožemio organinė medžiaga, rykštinès soros pasėlių tipai, rykštinès soros produktyvumas. 